\title{
Communication
}

[Comunicação]

\section{Spawning failure in Brycon amazonicus may be associated with ovulation and not with final oocyte maturation}

\author{
[A falha na desova de fêmeas de Brycon amazonicus pode estar relacionada com ovulação e não \\ com a indução a maturação final dos ovócitos]
}

\section{P. Hainfellner, T.G. De Souza, M.E. Muñoz, G. A. Freitas, S.R. Batlouni*}

Universidade Estadual de São Paulo - UNESP-Jaboticabal - Jaboticabal, SP

\begin{abstract}
Migratory fish kept in captivity may exhibit gonads that develop to advanced stages of maturation but do not reach the final stages of the reproductive process (final maturation of oocytes, ovulation and spawning). These final stages can only be produced through hormone treatments (Mylonas et al., 2010). According to Zohar and Mylonas (2001), the most common reproductive dysfunction in fish is the fail of the vitellogenic oocytes undergo to final oocyte maturation (FOM). Additionally, it is well known that dysfunctions may occur in female broodstock in fish (Bobe and Labbé, 2010; Mylonas et al., 2010). However, there is a lack of information on the mechanisms that cause spawning failure in South American migratory breeders. The chief purpose of this study was to evaluate the possible reasons for unsuccessful spawning in the native South American migratory species, Brycon amazonicus, induced to spawning with carp pituitary extract.
\end{abstract}

This study was conducted in an Aquaculture Center in October 2008, using there $B$. amazonicus females, selected for induced breeding experiments (a $0.6 \mathrm{mg} / \mathrm{kg}$ dose of carp pituitary extract followed by a $5.4 \mathrm{mg} / \mathrm{kg}$ dose, with a 12-hour interval between doses). Four to eight hours after the second hormonal doses, females were extruded, anesthetized with a benzocaine solution and sacrificed for the collection of ovaries. The total number of oocytes released from each female (absolute fecundity) was estimated (Table 1). The gonadosomatic index (GSI) was determined with the formula: \{(weight of remaining ovary + released oocyte mass/total weight) $\mathrm{x} 100\}$. Fragments of the ovaries were fixed and histologically analyzed. Histological sections were utilized to determine the frequency of different oocyte types by examining all oocytes present in 30 microscopic fields (ten fields per region, 5x magnification). Oogonia were not included in the analysis. The following oocyte types were considered: previtellogenic (PVO); cortical alveoli (CAO); immature vitellogenic oocytes (IVO); germinal vesicles that broke down but did not ovulate (NO); post-ovulatory follicles (POF); and atretic oocytes (AO).

Only one out of the three injected females actually spawned (Table 1). According to Zohar and Mylonas (2010), three basic kinds of problems are associated with reproductive difficulties in female broodstocks: a) fish may fail completely to undergo vitellogenesis when maintained in captivity; b) vitellogenesis may progress normally, but the post-vitellogenic oocytes fail to undergo final oocyte maturation, ovulation and spawning; and c) oocytes undergo normal vitellogenesis, final oocyte maturation and ovulation, but ovulated eggs are not released to the water. In this context, the results obtained in this study revealed a fourth type of problem. Oocytes attained final maturation, as indicated by germinal vesicle breakdown (GVBD). However, ovulation did not occur, and these oocytes remained attached to the ovaries (Figure 
1A-C). These females could not release individuated oocytes. They expelled clumps of NO (Figure 1D). In the ovaries of the females that did not spawn (NFs), the NO (23\%) remained attached to the ovary. The result of this situation was a low POF frequency (5\%) (Figure 2). However, the frequencies of $\mathrm{NO}$ and POF were 3 and $23 \%$, respectively, in the remaining ovary of the female that successfully spawned (SF). Both SF and NFs presented similar values of $\mathrm{POF}+\mathrm{NO}$ frequencies (30 and $26 \%$, respectively). This finding indicates that the hormone treatment was able to induce GVBD in a similar manner in all of the injected females.

Table 1. Reproductive parameters of Brycon amazonicus female that successfully spawned (SF) and of both females that did not spawn (NFs)

\begin{tabular}{cccccc}
\hline $\begin{array}{c}\text { Brycon } \\
\text { amazonicus }\end{array}$ & $\begin{array}{c}\text { Total weight } \\
(\mathrm{kg})\end{array}$ & $\begin{array}{c}\text { Remaining ovary } \\
\text { weight }(\mathrm{kg})\end{array}$ & $\begin{array}{c}\text { Released oocyte } \\
\text { mass }(\mathrm{kg})\end{array}$ & GSI $^{*}$ & $\begin{array}{c}\text { Absolute } \\
\text { fecundity } \\
\text { (oocyte/ fish) }\end{array}$ \\
\hline SF & 2.00 & 0.146 & 0.15 & 14.80 & $360,000.00$ \\
$\mathrm{NF}$ & 2.20 & 0.328 & 0.00 & 14.91 & $380,000.00$ \\
$\mathrm{NF}$ & 1.80 & 0.280 & 0.00 & 15.56 & $330,000.00$ \\
\hline
\end{tabular}

*Gonadosomatic index (GSI) calculated by the formula: \{ (weight of remaining ovary + released oocyte mass/total weight) $\mathrm{x} 100\}$.

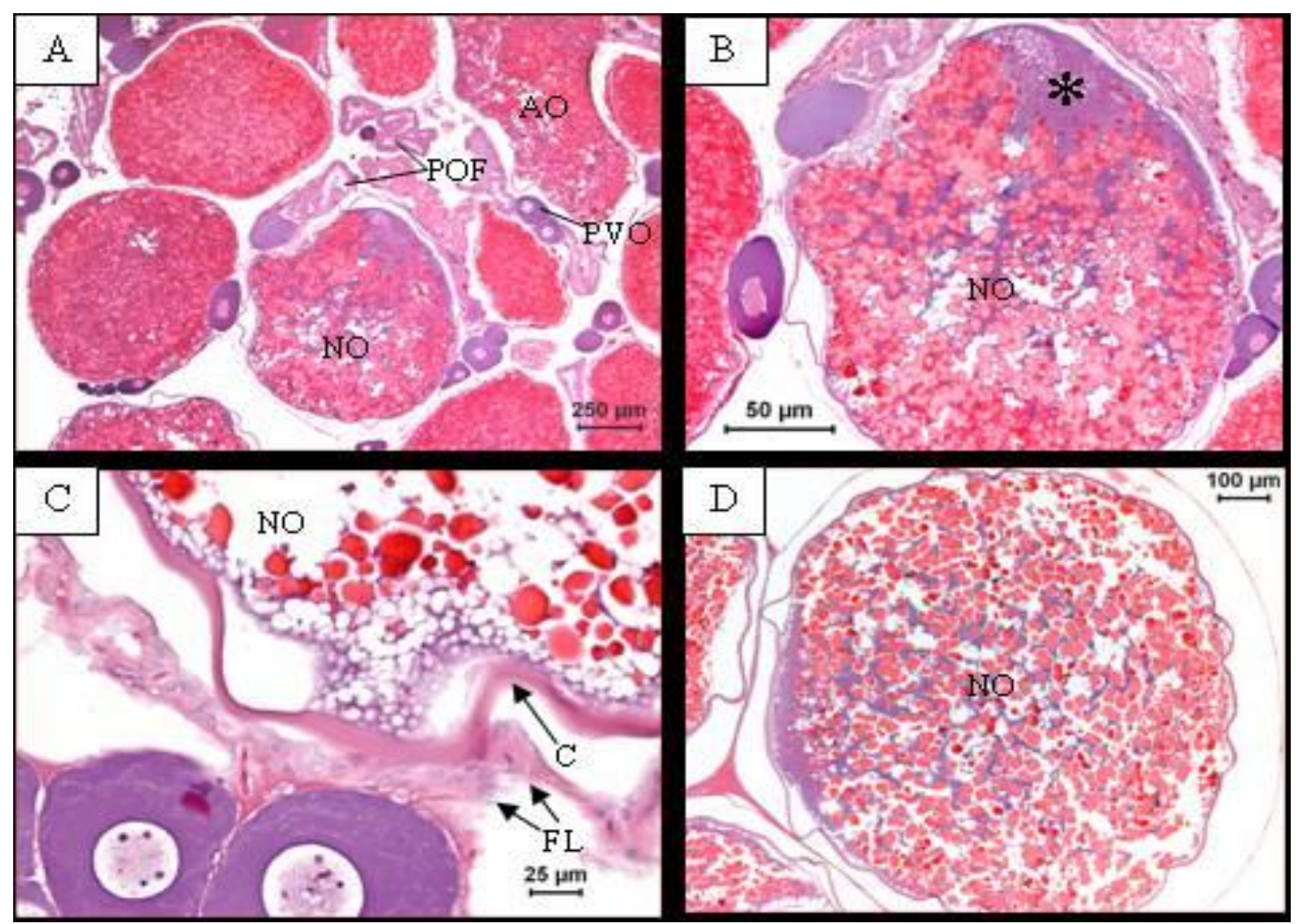

Figure 1. Brycon amazonicus. (A-C): histological evaluation of ovaries of a female that did not spawn after hormonal treatment. A: General view of a remaining ovary. B: Higher magnificence of the NO oocyte shown in 1A. Observe the nuclear material placed at the cell periphery and the absence of a nuclear membrane (*). C: Detail of a NO showing that the corion attached to the follicular layer (FL). D: Detail of the clumps released by NF formed by NO attached to each other released by D. AO: atretic oocyte; C: corion; FL: follicular layer; NO: oocytes presenting germinal vesicle breakdown but not ovulated; POF: post-ovullatory follicle; PVO: previtellogenic oocyte. 

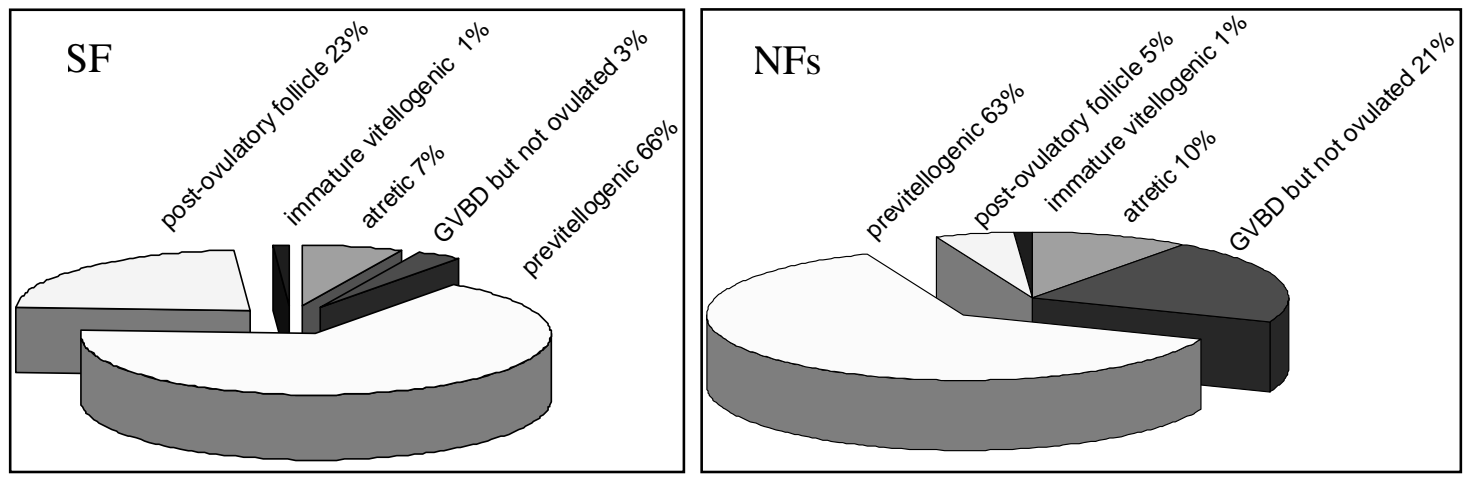

Figure 2. Brycon amazonicus. Percentage distribution of different types of oocytes present in the remaining ovaries of females after hormone treatment. SF: females that successfully spawn; NFs: mean values of females that did not spawn.

The low frequencies of $\mathrm{AO}$ in $\mathrm{SF}$ and NFs (7 and $10 \%$, respectively) show that they were captured in sufficient time for spawning. These data strongly suggest that the failure in NFs was associated with unsuccessful ovulation but not with a failure to induce GVBD and FOM. In this context, it should be interesting to evaluate the role of each hormonal dose in this species as well as in other rheophilic species because the absence of spawning in captivity is found in most South American migratory native species. Moreover, it should be also interesting to evaluate the possibility of using substances beyond gonadotropins and GnRH, such as exogenous prostaglandins, to enhance the ovulatory processes once it has been shown that they are related to ovulation and successful spawning in other fish species (Listerand, Van Der Kraak, 2008; 2009).

Keywords: fish, Brycon amazonicus, oocyte release, hormonal induction

\section{RESUMO}

Avaliaram-se os possíveis mecanismos envolvidos com a falha na desova de matrinxãs (Brycon amazonicus), submetidas à indução hormonal por extrato bruto de hipófise de carpa. Para tal, após a extrusão, os ovários foram coletados e analisados histomorfometricamente. Nas fêmeas que não desovaram (FNDs), a maioria dos ovócitos vitelogênicos remanescentes nos ovários atingiu a maturação final, apresentando quebra de vesícula germinativa, mas não foram ovulados (NOs). Consequentemente, estas fêmeas apresentaram frequências mais baixas de folículos pós ovulatórios (5\%) quando comparadas com a que desovou (FD) (23\%). Com relação aos NOs, os valores se inverteram e a frequência destes nas FNDs (21\%) foi maior do que na FD (3\%). Estes dados indicam que as falhas na desova desta espécie estão provavelmente relacionadas com a ovulação, uma vez que a maturação final dos ovócitos ocorre de forma similar tanto nas FNDs como na FD. Os dados sugerem que as substâncias que promovem a ovulação, como as prostaglandinas, podem aumentar o sucesso de desova em peixes reofílicos.

Palavras-chave: matrinxã, desova, indução hormonal

\section{REFERENCES}

BOBE, J.; LABBÉ, C. Egg and sperm quality in fish. Gen. Comp. Endocrinol., v.165, p.535-548, 2010.

LISTER, A.; VAN DER KRAAK, G.J. An investigation into the role of prostaglandins in zebrafish oocyte maturation and ovulation. Gen. Comp. Endocrinol., v.159, p.46-57, 2008.

LISTER, A.; VAN DER KRAAK, G.J. Regulation of prostagladin synthesis in ovaries of sexually-mature zebrafish (Danio rerio). Mol. Reprod. Dev., v.76, p.1064-1075, 2009.
MYLONAS, C.C.; FOSTIER, A.; ZANUY, S. Broodstock management and hormonal manipulations of fish reproduction. Gen. Comp. Endocrinol., v.165, p.516-534, 2010.

ZOHAR, Y.; MYLONAS, C.C. Endocrine manipulations of spawning in cultured fish: from hormones to genes. Aquaculture, v.197, p. 99-136, 2001. 